Kayryakova, K. (2021). The concert as a form of presenting bulgarian dance art on the basis of folklore. Culture and arts in the context of cultural beritage. Klironomy, 3 (3), 136-149. Hlučín-Bobrovníky: "Anisiia Tomanek" OSVČ. (in Bulgarian)

Кайрякова, К. (2021). Концертьт - форма на представяне на бъмгарското танцово изкуство на фолклорна основа. Culture and arts in the context of cultural heritage. Klironomy, 3 (3), 136-149. HlučínBobrovníky: "Anisiia Tomanek" OSVČ.

DOI: $10.47451 /$ art2021-10-002

EOI: $10.11249 / \operatorname{art} 2021-10-002$

The paper is published in Crossref, Internet Archive, ICI Copernicus, Google Scholar, Academic Resource Index ResearchBib, JGate, ISI, CiteFactor, Journal Factor, eLibrary, Ukrainian National Library databases.

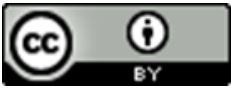

Katya Kayryakova

Associate Professor, Doctor of Choreography

Department of Arts

Faculty of Architecture

Varna Free University "Chernorizets Hrabar"

Varna, Bulgaria

E-mail katia.kairiakova@vfu.bg

\title{
The concert as a form of presenting Bulgarian dance art on the basis of folklore (in Bulgarian)
}

\section{Abstract:}

The challenges facing the performing folk art today are different, but perhaps the biggest among them is the form of its presentacion. Bulgarian folk dance has always enjoyed great interest. Over the years, the audience demand has been constantly growing, which necessitates the need to focus on the quality of its performance in response to the spiritual and cultural needs of the audience. The object of this research is the concert as a form of presenting Bulgarian dance art on the basis of folklore. The purpose of the submitted work is to analyse the specific features of the concert as a form of presenting Bulgarian dance art on the basis of folklore; to highlight the leading role of the director in the whole course; from the ideological conception to the realisation of the art programme. This purpose also includes the tasks related to its realisation, to be precise, the interpretation of a concert and performance as a subject of the director's strategy; following the process of scenario creating and showing up the special features of the performance, introducing the stage folklore art; the special role of the director regarding the complete art product- from the beginning to the end. The topic leads to a wide analysis, which is not possible to be presented in one report. That is why, the expression of the whole idea is limitted and analysing only the concerts, the contents of the music and dance on the basis of the Bulgarian folklore.

Key words: folklore, dance art, concert, performance, director.

Катя Кайрякова

АОцент, Аоктор по хореография катедра „Изкуства“ 
Архитектурен факултет Варненски свободен университет „Черноризец Храбър“ Варна, Бъмгария E-mail katia.kairiakova@vfu.bg

\section{Концертьт - форма на преАставяне на бъмгарското танцово изкуство на фолкиорна основа}

\section{Pезгоме:}

Различни са предизвикателствата преА сценичното фолклорно изкуство днес, но може би най-голямото сред тях е формата на неговото представяне. Българският фолклорен танц се е радвал винаги на огромен интерес. В годините зрителското търсене непрекъснато нараства, което налага необходимостта от насочване вниманието върху качеството на неговото представяне в отговор на Ауховните и културни потребности на публиката Обект на настоящото изследване е концертьт като форма на представяне на българското танцово изкуство на фолклорна основа. Целта на предложения текст е Аа анализира спецификата на концерта като форма на представяне на българското танцово изкуство на фолклорна основа, Аа открои водещата роля на режисьора в цялостния процес от илейната концепция Ао реализацията на художествената програма. Тази цел формулира и задачите свързани с

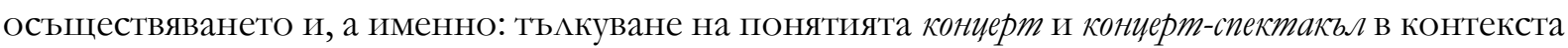
на режисьорската стратегия, проследяване на процеса на изгражАане на сценария и открояване спецификите в концерти представящи сценичното изкуство на фолклорна основа. Аа се очертае мястото на режисьора от идеята до представянето на цялостно завършен художествен продукт. Темата насочва към изключително широко изследване, което не би могло да се осьществи в рамките на една публикация и това налага необходимостта от известно ограничение, изразяващо се в анализа на концерти, съдържанието на които се състои от музикални и танцови произведения на фолклорна основа.

Ключови думи: танцово изкуство на фолклорна основа, концерт, спектакъ , режисьор.

\section{Въведение}

C появата на сценичното танцово изкуство на фолклорна основа се утвърждава и концертът като форма на представяне на това изкуство. В годините зрителското търсене и потребление на различните концертни форми непрекъснато нараства. Културното пространство Анес е наситено с огромен брой концерти, в основата на които е траАиционната музикална и танцова култура, но за да остане трайно впечатлението от всеки един от тях, то той трябва да бъде ярък и впечатляващ. Усещането за грандиозен празник остава задъцго в паметта на публиката, ако е постигнато емоционалното уАовлетворение от преживяното събитие и препотвърАени траАиционни 
културни ценности. В контекста на високия зрителски интерес организацията и реализацията на всеки такъв концерт е необходимо да бъде максимално близо да истинско съвършенство. За постигане на това несъмнено водещата роля е на режисьора, който изготвя съдържанието, определя темпо-ритьма и визията на концерта, негова е отговорността за прецизното отработване на всеки детайц от илейната концепция до реализацията му. В театралното изкуство темата за режисура и режисьор излиза на преден план едва в края на XIX век като „... п представите на критиката като чяло режисьорът е човекът, който съчетава художествени и административни функиии, но той се разбира най-вече като помощно лище при подготовката на ролята на актьора. "(Аечева, 2006:74). От втората половина на XIX век в европейската култура режисурата се утвърждава като нов тип театрална практика. Съществуват множество научни изследвания в областта на композицията и режисурата на танцово произведение и цялостен танцов спектакъц със собствена драматургия. Установицата се водеща роля на режисьора в практиката и спецификите на режисурата като дейност в концертите на фолклорна основа все още рялко са обект на теоретични изследвания. Отнесен кьм оная част от зрелищната култура, която възпитава не само отделната Аичност, а и цели колективи участници в осъществяването му, определя и необходимостта от повече теоретични разработки свързани с това поле на научното знание. Написаното до тук обуславя актуанността на предложения текст и очертава посоката на изложението. Стремежът е да бъдат изследвани и анализирани спецификите в представянето на сценичното творчество на фолклорна основа, да се обективира водещата роля на режисьора в изграждането на пластическата композиция на цялостния художествен продукт.

Целта на настоящото изследване е Аа анализира спецификата на концерта като форма на представяне на българското танцово изкуство на фолклорна основа и да открои водещата роля на режисьора в цялостния процес от идейната концепция до реализацията на художествената програма.

Задачите свързани с осъществяването на поставената цел вкАючват:

- тълкуване на понятията концерт и концерт-спектакъц в контекста на режисьорската стратегия;

- $\quad$ анализ на основните компоненти определящи характерните особености в режисурата на концерт или концерт-спектакъц с произведения на фолклорна основа; 
- проследяване на процеса на изграждане на сценария и открояване спецификите в концерти представящи сценичното изкуство на фолклорна основа;

- аргументиране водещата роля на режисьора от илеята до представянето на цялостно завършения художествен продукт.

Спецификата на изследването предполага използване на широк спектьр от похвати и методи от теоретичната област на хореографията, културологията, историята на изкуството. Метод на сравнителен анализ - като основа за извеждане на специфичното качество и съдържание на изследвания проблем, емпиричен изследователски метод - проучване на видео, аудио и текстови източници с информация свързана с представянето на българското танцово изкуство на фолкцорна основа.

Основните източниците на информация използвани в настоящото изследване са трудовете на утвърдени изследователи в областта на хореографското и театрално изкуства в България. В Аопълнение са проучвани и материали от чуждестранни автори, както и енциклопедична митература.

\section{1. Същност на понятията концерт и концерт-спектакъм}

В превод концерт / от матински - concerto/ означава състезавам се и води началото си от Аревността при организирането на разАични състезания, в това число и в областта на художественото изпълнение. Еволюцията на това понятие води до съвременното му тълкуване. В българския тълковен речник значението на думата концерт се определя като изпллнеие пред публика на избрани и подредени музикални, литературни и други творби (Значение на Аумата концерт, 2013). Определението в Большая советская энциклопедия по съдържание не се отличава, като и там съвременното разбиране за концерт означава публично представяне на артисти по предварително определена програма. В съвременната социокултурна реалност спецификата на концерта, като форма на културна и развлекателна дейност, представя значителен потенциал, който е особено важен в процеса на развитие и възпитание на публики с високи естетически критерии. В зависимост от съдържанието си концертите биват разАични видове - вокални, инструментални, танцови, смесени и Ар., както и различни по своята жанрова определеност - фолклорни, класически, смесени и Ар. Много често при представяне на фолклорното сценично изкуство в нашето съвремие вместо концерт се употребява терминът спектакъл. Спектакъц

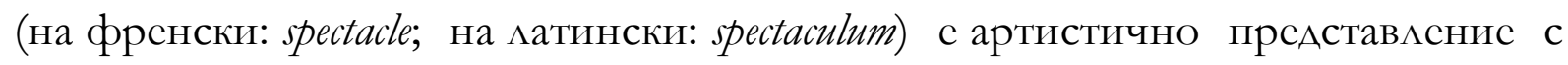


елементи на зрелищност, което се представя на голяма сцена преА публика. Първоначално спектакли са се наричали произведенията в театралното изкуство, в създаването на които е участвац целият актьорски състав. В процеса на еволюционното развитие на понятието спектакъл, като художествена форма, постепенно се утвърждава принципа на ансамбловостта, който предполага съгласуваността на всички изпълнители и обмисленото използване на изразните средства. В основата на театрацния спектакъц межи митературно произведение или сценарий. В съвременните театри създаването на театралния спектакъц се ръководи от режисьор-постановчик съобразно неговият собствен замисъ. Съществуват множество вицеозаписи на театрални постановки и филми, в основата на които е Ааден театрален спектакъ, които са определени със съчетанието филм-спектакъл. С развитието на телевизията се появява и жанра телевизионен спектакъл, който се записва и адаптира в съответствие с телевизионната специфика. Режисурата на този тип спектакли също се осъществява от режисьор, чиято концепция е подчинена на спецификата на съответния жанр. Етимологията на двете понятия конщерт и спектакъл се припокрива, но съотнесени в изкуството на фолклорна основа коректното определение е конщерт-спектакъл. Конщертът определя художествените прояви, съдържащи в програмата си музика, песни и танци на фолклорна основа, а с понятието конщерт-спектакъл могат да се афишират концерти, чието съдържание е подчинено на определена тема. Когато номерата в един концерт са подбрани и подредени, щото да създадат впечатление за еАно цяло театрално представление най-вярно и коректно към съдържанието е съчетаването на Авете понятия и определянето на художествения продукт като конщерт-спектакъл.

Творчеството в танцовото изкуство на фолклорна основа показва уникалността на традиционния български танц и това определя значимостта на начина на представяне пред публика. В повечето случаи произведенията на тази основа намират място в така наречените смесени концерти и по жанр и по форма и по място на реализация. Самостоятелни концерти съставени само от танцови произведения на фолклорна основа са много рядко. И това е така, защото колкото и разнообразно да е съдържанието на еАин концерт от различни по форма и етнографска принадлежност произведения, то неминуемо идва момент на отегчение в публиката и такъв тип концерт губи сугестивната сила на своето въздействие.

Анес в редки случаи в афишите на така наречените фолклорни концерти присъства името на режисьора. Както при много Аруги професии в областта 
на сценичните изкуства режисьорите на фолклорни концерти често изграждат уменията си в процеса на работа. В повечето случаи в професионалното изкуство на този жанр функциите на режисьор се изпьлняват от хореографите, макар цялостната концепция за всеки отделен концерт и програмата, определяща съдържанието да се приема от художествените съвети. Спецификата на хореографията като вид изкуство определя и съдържанието на професионалното обучение по хореография, което в България възниква през втората половина на XX век. Основна тема в обучението е композицията и режисурата на танцово произведение и танцов спектакъц. Това определя и водещата роля на хореографа в оформянето на режисурата на цялостното представяне на танцовото изкуство на фолклорна основа. В един периол до 1989 г. при представянето на мащабни проекти за режисурата им са привличани специалисти режисьори като Асен Траянов, Стефан Мушатов, Ааска Минчева и Ар., но техните имена са свързани най-вече в областта на телевизионната режисура с представяне на фолклорни образци. С настьпилата промяна в обществено-икономическия живот от 1989 г. Ао Анес изключително рядко функциите на режисьор на определен концерт се изпълняват от Аруг специалист извън прякото ръководство на самите участници в концерта.

\section{2. Особености на режисурата и ролята на режисьора в представянето на сценичното творчество на фолклорна основа}

Какво точно обхваща режисурата на един концерт, чието съдържание са произведения на фолклорна основа? На първо място е поводът за представянето му, който определя и тематичната област. Аали е празничен, коледен, великденски или подчинен на реализацията на Аруга илея, Аали е само концерт или концерт-спектакъц. Тематичността съответно определя и съдържанието на отделните номера и оформянето им в програма на представяне. Изкцючително важен компонент е мястото на представяне, което от своя страна оказва влияние върху общата визия и звучност на концерта. „Режисурата е изкуство за създаването на хармоничен и иялостен спектаквл посредством организачията на всичкте му елементи на основата на творческия замисъл на хореографа-режисьор“ (Ауканов, 2012:40). Това заключение би могло Аа бъде безпроблемно отнесено и към определяне режисурата на концерт, като само понятието „хореограф-режисьор“ бъде заменено с режисьор. Анализираните от Ауканов компоненти в режисьорския замисъц при създаване на хореографско произведение са напълно съотносими и като важна съставна част от режисьорския замисъц при реализиране на концерт. Несъмнено на 
първо място е Араматургичната основа, т. е. намирането на образното решение на концерта, характеристика на отделните номера в съдържанието, определяне времетраенето на концерта и неговия темпо-ритьм, художественото оформление и най-важния компонент - определяне на посланието - в отговор на въпросите: защо се представя този концерт; какво трябва да предизвика в съзнанието на зрителя; какво въздействие върху публиката се очаква. Казаното до тук очертава и главните особености на режисурата на концерт или концертспектакъц с произведения на фолклорна основа, а именно:

- Създаване на илейна концепция;

- $\quad$ Написване на сценарий и изготвяне на програма;

- Оформяне на цялостната визуализация .

Илейната концепция е изключително важна за определяне формата на представяне на сценичното фолклорно изкуство - концерт или концертспектакъц. Определената форма дефинира съдържанието, композицията, могиката на преходите от един номер към Аруг, темпо-ритьма, възможностите за разкриване на темата и илеята, сценографията и цялостното художествено оформление. ИАейната концепция представя не само темата и идеята на съдържанието, но и как точно те ще бъдат защитени с представянето на отАелни номера съчетани в един завършен цялостен художествен продукт. Когато формата е концерт-спектакъ, много често, идейната концепция се съдържа в самото заглавие. В повечето случаи то е метафорично, образно и насочващо емоционално вниманието към основната илея. Например „Старо имане“ на АНПТ „Пирин“, „Земята на Орфей“ на ФА „Тракия“, „Аиви ягоди“ на Национален ансамбъм „Филип Кутев“, „Път през Тракия“ на ансамблите „Тракия“ и „Странджа“ и много Аруги.

На следващо място по хронологичен реА, но не и по значение е изготвянето на сценария със строго подредените номера. Тематичността актуализира основанията за осъществяването на всеки концерт и несъмнено основен момент в изготвянето на сценария е да се насочи вниманието към тях. В своето изслелване „Сочинение танца“ Ростислав Захаров обръща специално внимание на програмата на балетния спектакъц. СпореА него „Създаването драматургията на балетния спектакъл, както и на всяко друго произведение от театралното изкуство, започва с появата на замисьла. Замисъльт обезателно включва в себе си темата и идеята на бъдешото произведение." (Захаров,1989:157) Това заключение може да бъде отнесено и към изготвянето на програмата на даден концерт или концерт-спектакъл. И тук на преден план излиза водещата роля 
на режисьора. Определена е темата на концерта, но самото съдържание и подрежАането на номерата е все още неизвестно, докато не се изясни какви точно художествени произведения ще се включат. Това предполага сериозно обмисляне на участващите и всички репертоарни еАиници, с които художествените колективи или инАивидуални изпьлнители разполагат. Важен определящ фактор ще бъде не само художествените качества, които притежава всяко отАелно изпъцнение, но и как точно ще помогне в разкриването на темата и внушаването на художествената идея на целия концерт. Безспорно е, че успехът му зависи не от големия брой изпъ ннения, а от интересния режисьорски замисъц и усещането за един цялостен художествен продукт, в който нищо не може да се отнеме или прибави. Необходимо е прецизиране на първия и последния номер от концерта. Особено важно е как започва концертьт, защото началото настройва и подготвя зрителя към бъдещото представление, а финацът трябва да бъде ярка и незабравима точка, която АъАго време ще се помни и ще остави чувството на удовцетвореност в публиката. Концертьт ще пожъне успех, когато програмата е съставена с постепенното нарастване на зрителския интерес. Най-Аинамичните и ярки номера могат да бъдат разположени на принципа на нарастването близко към финала. Много важно е да не се допуска еднообразие в подреждането на номерата по жанр и темпо-ритьм. Особено важен детайл в режисурата на концерт-спектакъц е съдържанието на програмата да бъде оформено с ясно изградена Араматургична Аиния подчинена на основната тема и илея.

Съществена част от режисурата на един концерт е цялостното аудиовизуално оформление. Сериозно предизвикателство е съчетаването на акустичните характеристики на отделните традиционни за българския фолклор инструменти и спецификите в озвучаването на вокалните изпълнения-акапелно и в съпровод. Създаването на цялостната звукова картина предполага ползването на голям брой и различни по форма микрофони и несъмнено специалист за работата със звуковата материя. Особено важна предпоставка за визуалното оформление е мястото на провеждане. Ако концертьт е на закрито сценографията ползва всички възможности, които предлага театралната сцена - кулиси, рампа, множество прожектори, завеса. Ако мястото на провежлане е открита сцена изграждането на сценография е съобразено с възможностите, които съществуват и несъмнено по-ограничени от тези на закрита сцена. Това в никакъв случай не ограничава истинския творец-режисьор, напротив Аава възможност за разгръщане на широка творческа фантазия и с ползването на съвременните 
технологични средства може да се изгради сценична атмосфера допринасяща за още по-силното въздействие на целия концерт.

В обобщение на всичко казано до тук на преден план се очертава водещата роля на режисьора. Той определя формата-концерт или концертспектакъц, основната илея, задачата и темпо-ритьма и след това изгражда представянето така, че драматургията да бъде защитена от естествено редуващи се номера и тяхното съотношение да бъде подчинено на общото художествено решение. Трябва да намери точно експозицията, развитието, кулминацията и финала, т.е. представянето да бъде изградено на принципа на музикалноАраматургическо действие, основата на което се явява отделния номер. Режисьорът създава особен род Аействие от сложните съчетания на танц, музика, осветление, озвучаване, усвояване на пространство, на което са разположени огромен брой хора.

Аъцгогодишната ми работа като ГАавен художествен ръководител на Ансамбъ $а$ за народни песни и танци „Шумен“ ми дава основание да подкрепя изложените до тук разсъждения с прилагането им в моята режисьорска практика. Ще Аам пример с концерт-спектакъла „ГАътка от живата вода“

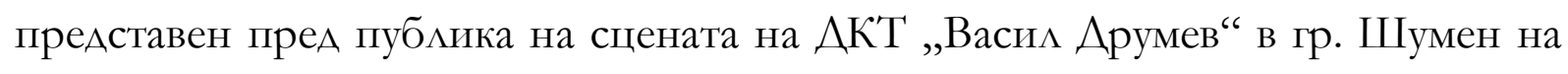
12.06.2015 г. Ансамбъц „Шумен“ представ фолклорен ансамбъ , съдържащ три звена - хор, оркестьр и танцов състав. Оформянето на концертната програма на такъв колектив изисква изява на всички от тях поотделно и заедно, което е предпоставка за сътворяването на еАин разнообразен, Аинамичен и вълнуващ спектакъ.

Концерт-спектакъцът „ГАътка от живата вода” представ $я в а$ еАна своеобразна асоциативна разходка в традиционния български празничнообреден календар. В основата на българските народни празници и обичаи е отразена мъдростта, органичното съчетание на практичността и духовността в екзистинциалното битие на старите българи. Българската обредна и празнична култура е изключително богата с прояви на творчество, които характеризират духовната култура на нашия народ. Народният стремеж към красота и творчество оформя зрелищно-развлекателната страна на част от календарните обичаи и обреди. Изследването на българския танцов календар открива, че в същото време „...музиката и тануа във фолклора никога не са били само развлечение, не са били нешо отделно от начина на живот и от законите, управляваши живота. Те са просто един от начините, по които се изказва и изживява, преоткрива и пресътворява всеки път отново мистерията на живота. "(Икиева и Щьрбанова, 1992: 93) 
Празнично-обредната система синтезира определени форми на художествената култура и винаги е била обект на творческо претворяване в сценични произведения на фолклорна основа. С навлизането на тематичната и сюжетна форма на танца в българската сценична хореография редица автори насочват вниманието си към теми и сюжети от празнично-обредния календар.

ИАейната концепция на концерт-спектакъца е подчинена на желанието зрителят да се потопи в атмосферата на българската традиция и да съпреживее вълненията и емоциите, съпътстващи живота на българина в определени моменти от сезоните на годината, благодарение на творчески претвореното и поднесено с красота и изящество изкуство на народната песен и танц. Това определи и съдържанието на отделните номера - ансамблови постановки, вокални изпълнения-солови и масови, акапелни и в съпровод. Като своеобразен преход към отделните картини бе вкцючен автентичен текст от народното песенно творчество. ИзпъАнението на този текст е от водеща, която олицетворява персонажа на българската Аевойка, през чийто поглеА, Аушевни вълнения и пряко участие, протичат събитията. Интересен факт е, че водещата съчетаваше в себе си актьорското майсторство на професионална актриса и умението Аа танцува български народни танци и това спомогна във финалния танци тя да се включи като една от всички танцуващи девойки в потвърждение на изказания от преди това текст.

Пролетта е този сезон на годината, в който се ражда животьт в природата, избуява надеждата за по-добро, появява се новото начало. Това определя и отправната точка за начало на спектакъла с появата на водещата и изпъ ннения с ведро настроение текст, съдържанието, на който насочва вниманието към първото изпълнение -„Аивдядовска Голяма Аазара”. Това е тематичен танц изпълняван само от девойки. Целта е интерпретирането на един определен момент-очакването на Аазаровден и всички емоции и въАнения, които всяка Аевойка преживява. Танцът няма характерната структура на обичая. Основната илея е да се разкрие крехката моминска чувствителност в очакване на получаване на сакралната сица „...nо време на своето посвещение в моминство, което като всяко посвешение предполага и едно „пвтуване в отвъдното”, в сакралния свят на предчите откьдето черпели и особената енергия за своето преминаване в ново качество". (Щърбанова, 1995:64-73) И макар и еднороден този танц поставя добро начацо на концерт-спектакъла съобразено с основната тема и идея, още повече, че на сцената се появяват значителен брой изпълнители - хор, оркестьр, танцьорки, които упльтняват сценичното пространство и създават една цветна картина на празнично веселие. Следват музикални и танцови изпълнения подредени 
както по хронологичен реА, съб人юдавайки годишните сезони, така и осмислени и съчетани като съдържание, Аинамика и контраст:

- Вокални изпълнения - солист с оркестьр с изпълнение на песен от тракийска етнографска област и шопски припевки изпълнени от Аамски квартет, акапела;

- Водеща - текст насочващ към празника Гергьовден;

- „Гергьовден“ - ансамблова постановка с участието на трите звена;

- Водеща - текст пресъздаващ душевните вълнения на девойката, която изпраща своя Аюбим овчар и страда от временната им разАяла;

- Акапелна песен в изпълнение на хора, на фона на която върви изпълнение на танцов етюд пресъздаващ съня на овчаря, който също страда от разАялата с Аюбимата си;

- Вокално изпълнение на хор и оркестьр, контрастно като настроение и темпо;

- $\triangle$ ва танца - мъжки и женски - „Аобруджанци“ и „Влаинки“ от Аве разАични етнографски области водещи повестованието към метния цикъц от празнично-обредния календар.

- Вокален блок, който съдържа три изпълнения разнообразни по своята темпова и изпълнителска същност;

- Водеща - преходен текст към есенните празници с мегданските веселия, на които най-силно се осъществява общуването на момите и ергените и припламването искрите на цюбовта;

- „Мома от село ке бега“ - ансамболова постановка с участието на трите звена;

- Оркестрово изпълнение - като апотеоз на всеобщото веселие;

- Водеща - текст съдържащ приканването на всички за посрещане на коледарите;

- Коледни песни в изпълнение на мъжка вокална група;

Може да се приеме, че кулминацията на концерт-спектакъла съвпада с финалното изпълнение на „Тракийски танц“, в който участие вземат и трите звена на ансамбъла. Вплетено в него прозвучава и авторския текст на Борислав Геронтиев, който съдържа в себе си цялото преклонение към творческия гений на българина и създава усещането за национална гордост и патриотизъм.

В общото сценично оформление се използваха съвременните технически възможности на мултимедията и художественото осветление, предимства на 
съвременната визуална култура, подчинени на идеята за засилване художественото въздействие на спектакъла. Сценографията вкцючваше три екрана, на които се редуваха картини и клипове съобразно сценичното Аействие. ИзкАючително професионално бе озвучаването на такъв спектакъ, което определи и съчетаването на разАични видове микрофони.

\section{Аискусия}

Настоящото изследване на концерта като форма на представяне на българското танцово изкуство на фолклорна основа поставя проблема за режисурата и водещата роля на режисьора от идейната концепция Ао реализацията на художествената програма. Режисурата на формите на представяне на сценичното фолклорно изкуство може да се приеме като една Аиалектическа връзка межАу два взаимно свързани основни компонента съдържание и форма Реализирането на концерт или концерт-спектакъц се определя от съдържанието и формирането на идейната концепция на режисьора. В този смисъц режисьорът става водеща фигура в целия процес на подготовка и реализиране на определената форма.

\section{Закиючение}

Представянето на фолклорното сценично изкуство в съвременната социокултурна реалност се наложи като значима дейност способстваща за културното възпитание на мичности с устойчива ценностна ориентация. Множество концерти и концерт-спектакли доказват своята жизнеспособност и заемат място среА най-ценните и гледани продукции в областта на сценичното фолклорно изкуство. Силата на художественото внушение при осъществяване на всеки еАин от тях зависи от професионалния подход към цялото и всеки отделен детайл. Успешните и запомнящи се спектакли показват овлаАян съвременен художествен синтез съчетаващ в себе си разАични видове изкуства.

По пътя на творческата интерпретация и теоретичното изследване в преАложения текст се постигна основната цел в доказване на тезата, че изграждането на режисьорската стратегия на концерт или концерт-спектакъц преАполага широк спектьр от знания - залъцбочено познаване на българската фолклорна традиция, спецификите на музикалното и танцовото изкуства, възможностите на сцената, предизвикателствата преА реализацията на музикалната звукова картина, мултимедията и художественото осветление и несъмнено принципите и подходите при режисиране на ярък и запомнящ се художествен продукт с висока естетическа стойност. Несъмнено режисьорът е 
водещата фигура - от идеята до реализацията и това предопределя овладяването на оригинални творчески подходи, нови решения за съвременна художествена интерпретация на традиционната българска празничност и обредност, защото Авижението към уникалната Аушевност на българина ни обогатява и утвърждава.

В обобщение на резултатите от теоретичния и художественоестетически анализ могат да бъдат обособени следните изводи:

- ИАейната концепция опрелеля формата - концерт или концерт-спектакъ формулира темата и илеята;

- Прецизното изготвяне на сценария се определя не само от художествените качества на отделните изпълнения, но и как точно те се вписват в общото звучене на цялото и способстват за разгръщане на темата и защитаване на художествената идея;

- Оформлението на художествения продукт е подчинено на идеята за създаване на цялостна звукова и визуална картина подчертаваща неоспоримите качества на фолклорната музика и танц;

- Режисьорът е този, който разполага с огромния арсенал от изразни средства и от него зависи в каква посока те ще бъдат насочени, каква ще бъде тяхната функция, съобразно формулираната от него тема и илея.

\section{Използвани източници:}

Абрашев, Г. (2001) Композичия и форми на таниа. София: Наука и изкуство. Большая советская энциклопедия (2013, 10 април). Взето на 3 октомври 2021 г. OT

https://dic.academic.ru/contents.nsf/bse/?f=0JrQvtC80LA=\&t=0JrQvtGA 0LI=\&nt $=1422 \& p=2$

Аечева, В. (2006). Към проблема за режисурата. Българският театър между двете световни войни. София: „Просвета-София АА““

Захаров, Р. (1989). Сочинение танща. Москва: „Искусство“.

Илиева, А., Щърбанова, А. (1992). Български тануов календар. Музикални хоризонти. София кн. 5.

Ауканов, П. (2012). Хореорафска композичия и режисура. София: Аефекто.

Николова, К. (2000) Експресионистичният театър и езикът на тялото. София: УИ „Св. Св. КАимент Охридски“.

Станиславский, К. С. (1976) Моят живот в изкуството. София: Наука и изкуство. 
Значение на думата концерт (2013, 7 март). Взето на 3 октомври 2021 г. от http://talkoven.onlinerechnik.com/duma/концерт

Щърбанова, А. (1995) Таниът като пътуване в света на сакралното. Български фолклор. София. 